\title{
ANALISIS KARAKTERISTIK KEUANGAN TERHADAP INCOME SMOOTHING DENGAN STRUKTUR KEPEMILIKAN SEBAGAI PEMODERASI
}

\section{FINANCIAL CHARACTERISTICS ANALYSIS OF INCOME SMOOTHING WITH OWNERSHIP STRUCTURE AS A MODERATOR}

\author{
E. Suhaeni ${ }^{1}$, S. Djaddang1, K. Anwar ${ }^{1}$, Y. Triwidatin ${ }^{2}$ \\ 1) Magister Akuntansi Fakultas Ekonomi Universitas Pancasila \\ 2) Program Studi Akuntansi Fakultas Ekonomi Universitas Djuanda Bogor \\ Jl. Tol Ciawi No. 1, Kotak Pos 35, Kode Pos 16720, Telp/Fax : (0251) 8245155 \\ E-mail: endangsuhaeni2@gmail.com ${ }^{1}$, yuppy_triwidati@unida@ac.id ${ }^{2}$
}

\begin{abstract}
The purpose of this research is to examine the effect of firm value, company size, earnings persuasiveness, managerial ownership and institutional ownership on income smoothing in national private banking companies in Indonesia. the samples in this study amounted to 70. The data were tested using structural equation models (SEMWarp-PLS 6.0).

The test results show that earning per share has a significant positive effect on income smoothing. This shows that the greater the EPS Managerial Ownership and Institutional Ownership have a positive effect on income smoothing,Price Book Value moderated by institutional ownership influences significantly and is proven to be full moderation. Size is moderated by institutional ownership and has a significant effect as pure moderation while earning per share is moderated by managerial ownership, which is proven to be significant as quasi moderation.
\end{abstract}

Keywords:

Income smoothing, company value, company size, earning per share, managerial ownership and institutional ownership

\begin{abstract}
ABSTRAK
Tujuan dari penelitian in adalah untuk menguji pengaruh dari nilai perusahaan, ukuran perusahaan, earning pershare, kepemilikan manajerial dan kepemilikan institusional terhadap perataan laba pada perusahaan perbankan swasta nasional yang ada di indoensia. sampel dalam penelitian ini berjumlah 70. Pengujian data menggunakan model persamaan struktural (SEMWarp-PLS 6.0).

Hasil pengujian menunjukkan earing per share berpengaruh positif signifikan terhadap perataan laba. Kepemilikan Manajerial dan Kepemilikan Institusional berpengaruh positif terhadap perataan laba. Price Book Value dimoderasi oleh kepemilikan institusional bepengaruh sigifikan dan terbukti sebagai full moderasi. Size dimoderasi oleh kepemilikan institusional berpengaruh signifikan dan terbukti sebagai pure moderasi sedangkan earning per share dimoderasi oleh kepemilikan manajerial terbukti signifikan sebagai quasi moderasi.
\end{abstract}

Keywords:

Income smoothing, company value, company size, earning per share, managerial ownership and institutional ownership 


\section{PENDAHULUAN}

Laporan keuangan adalah suatu informasi yang berguna sebagai suatu pengambilan keputusan ekonomi. Pemakai laporan keuangan dibedakan menjadi beberapa yaitu pemegang saham, pemerintah, karyawan, kreditur dan masyarakat. Sering kali perhatian investor hanya terpusat pada laba sehingga sering tidak memperhatikan prosedur yang digunakan untuk menghasilkan informasi tersebut (Bettie et al,1994) dalam Rio Nur Agustianto. Hal ini menjadi pemicu manajemen melakukan tindakan yang membuat laporan keuangan terlihat lebih sehat secara financial yaitu dengan melakukan tindakan perataan laba (income smoothing)

Ukuran perusahaan merupakan nilai yang menunjukkan besar kecil perusahaan. Perusahaan besar mendapatkan pengawasan yang lebih ketat dari investor (Iskandar dan Suardana, 2016). Fluktuasi laba yang besar menunjukkan risiko yang besar dalam investasi sehingga mempengaruhi kepercayaan investor terhadap perusahaan. Semakin besar ukuran perusahaan maka semakin besar kemungkinan manajemen melakukan praktik perataan laba (Iskandar dan Suardana, 2016). Penelitian umi martini Aditya denny os (2012) menunjukan bahwa ukuran perusahaan berpengaruh positif terhadap perataan laba. Bertentangan dengan penelitian Sherlita dan Kurniawan (2013), Cahyani (2012) yang menyatakan ukuran perusahaan tidak berpengaruh terhadap perataan laba.

Semakin tinggi nilai perusahaan maka perusahaan akan cenderung untuk melakukan praktik perataan laba, karena dengan melakukan perataan laba, variabilitas laba dan risiko saham dari perusahaan akan semakin menurun. Menurut Cahyani (2012), nilai perusahaan berpengaruh terhadap perataan laba. Hal ini tidak sejalan dengan penelitian Noviana dan Yuyetta (2011) yang menyatakan nilai perusahaan tidak berpengaruh terhadap perataan laba.

Earning per share ( EPS ) adalah suatu komponen penting dalam analisis perusahaan karena menunjukkan besarnya laba bersih perusahaan yang siap dibagikan untuk semua pemegang saham perusahaan. Para calon pemegng saham sangat tertarik dengan eps karena merupakan salah satu indicator keberhasilan suatu perusahaan.

Menurut Fachrorozi (2017),earning per share berpengaruh negative dan signifikan terhadap perataan laba.hal ini bertentangan dengan Indrimeidini (2017) yang menyatakan bahwa EPS berpengaruh positif dan signifikan terhadap perataan laba

Struktur kepemilikan manajerial dapat dilihat dari konsentrasi kepemilikan atau presentase saham yang dimiliki oleh komisaris, dewan direksi, dan manajemen yang tercantum dalam daftar pemegang saham. Presentase tersebut dapat diperoleh dari banyaknya jumlah saham yang dimiliki oleh manajerial. Meningkatkan struktur kepemilikan manajerial akan mensejajarkan kedudukan manajer dengan pemegang saham sehingga manajemen akan termotivasi untuk meningkatkan kinerja perusahaan (Anggraeni, 2013).

Herlinda Pratiwi dan Bestari Dwi Handayani (2014 ) kepemilikan manajerial dan pajak berpengaruh terhadap perataan laba hal ini berbeda dengan penelitian $\mathrm{Ni}$ Kadek Budi Puspitasari (2016) struktur kepemilikan manajerial tidak berpengaruh tetapi struktur kepemilikan institusional berpengaruh terhadap income smoothing 
hal ini berbeda dengan penelitian Sri Murti Hartati (2014) struktur kepemilikan institusional tidak berpengaruh terhadap perataan laba

Kepemilikan Institusional adalah kepemilikan saham perusahaan yang dimiliki oleh institusi atau lembaga seperti bank, perusahaan investasi dan kepemilikan institusi lain (Purwaningtyas, 2011). Semakin besar kepemilikan institusi hal ini berbeda dengan penelitian Menurut Shleifer dan Vishnya (1997), kepemilikan institusional sangat berperan dalam mengawasi perilaku manajer dalam mengambil keputusan yang oportunistik Man dan Wong (2013) menjelaskan pemegang saham yang berbentuk lembaga cenderung memperoleh lebih banyak informasi jika dibandingkan pemegang saham individu.

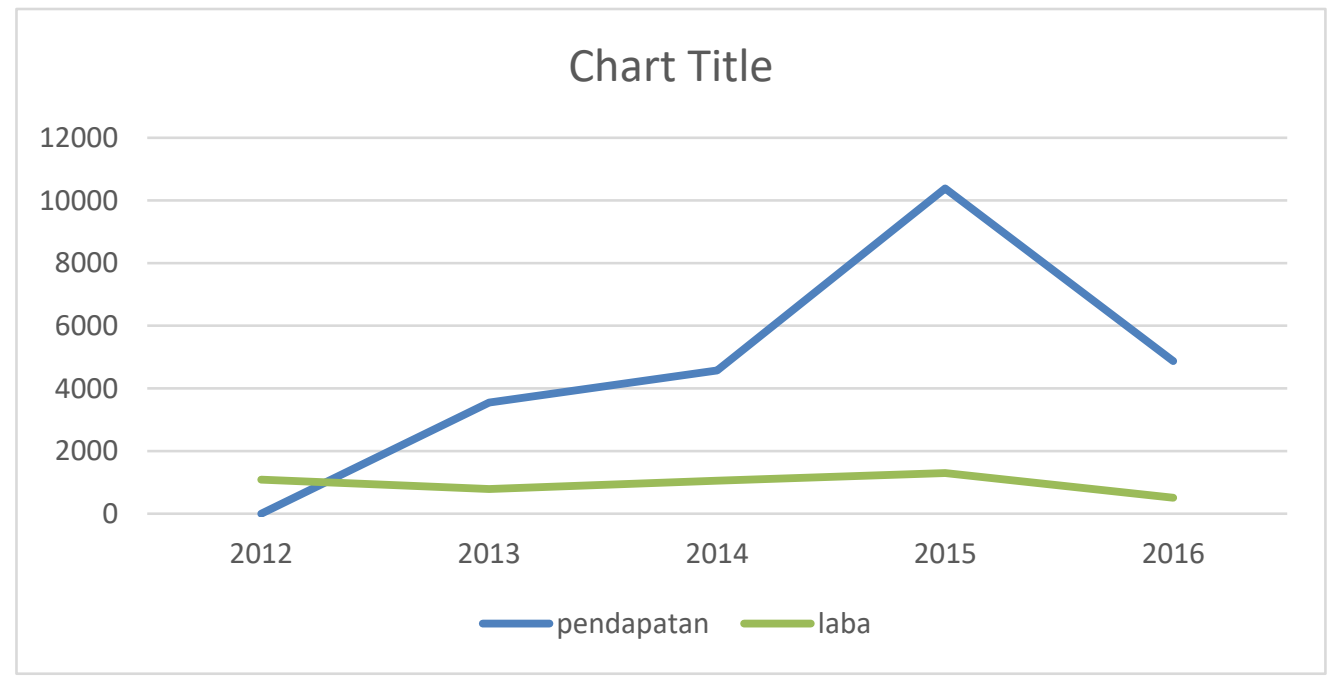

Gambar 1 Grafik rata rata

Gambar1

pendapatan dan perolehan laba pada perusahaan perbankan swasta di Indonesia yang terdaftar pada BEI periode 2012 - 2016

Gambar 1 menunjukkan bahwa nilai rata - rata pendapatan dari tahun 2012 mengalami penurunan pada tahun 2013 sebesar 571.054 rupiah. Untuk tahun 2014 mengalami kenaikan sbesar
1.025.036 rupiah. Untuk tahun 2015 mengalami kenaikan 3.536.669 rupaih dan untuk tahun 2016 mengalami penurunan sebesar 3.834.735 . sedangkan nilai rata - rata laba yang dihasilkan dari 
tahun 2012 mengalami kenaikan pada tahun 2013 sebesar 7.902.461 untuk tahun 2014 mengalami kenaikan sebesar 97.469.073. untuk tahun 2015 mengalami kenaikan 104.074.970 dan untuk tahun 2016 mengalami penurunan sebesar 3.798 .786 rupiah.

penelitian ini melibatkan factor nilai perusahaan, dan struktur kepemilikan yang belum dilakukan oleh peneliti sebelumnya.

\section{Telaah Teori dan Pengembangan} Hipotesis

\subsection{Teori Keagenan}

Menurut Jensen and Meckling (1976) mengatakan bahwa manajer didalam suatu perusahaan diibaratkan sebagai "agen" dan pemegang saham adalah "principal". Pemegang saham yang merupakan principal mendelegasikan pengambilan keputusan bisnisnya kepada manajer yang merupakan perwakilan atau agen dari pemegang saham.

\subsection{Perataan Laba}

Menurut Belkoui (2007:73) dalam Gantino (2015) Perataan laba adalah suatu upaya pengurangan fluktuasi laba dari tahun ke tahun dengan memindahkan pendapatan dari tahun-tahun yang tinggi pendapatannya ke periode-periode yang kurang menguntungkan.

\subsection{Nilai Perusahaan}

Menurut Nofrita (2013) Nilai Perusahaan adalah harga pasar dari saham suatu perusahaan yang terbentuk antara pembeli dan penjual pada saat terjadinya transaksi.

\subsection{Ukuran Perusahaan}

Menurut Pradipta dan Susanto (2012) dalam Gandasari dan Herawaty (2015) Ukuran perusahaan adalah suatu skala yang mengklarifikasikan besar kecilnya perusahaan menurut beberapa cara antara lain total aktiva dan nilai per saham".

\subsection{Earning Per Share}

Earning per share menurut tjiptono dan henry adalah suatu rasio yang menunjukkan berapa besar keuntungan (return) yang diperoleh investor atau pemegang saham per lembar saham

\subsection{Kepemilikan Manajerial}

Menurut Gideon (2005) dalam Agustin 2016 Kepemilikan manajerial adalah jumlah kepemilikan saham yang dimiliki oleh pihak manajemen dari seluruh modal saham perusahaan yang dikelola

\subsection{Kepemilikan Institusional}

Menurut Midiastuty dan Machfoedz, 2003). Kepemilikan institutional adalah saham perusahaan yang dimiliki oleh institusi atau lembaga seperti perusahaan asuransi, bank, perusahaan investasi dan kepemilikan institusi lain

\section{Kerangka Pemikiran Teoritis}

\section{H1 :Pengaruh Nilai Perusahaan terhadap Perataan Laba}

Nilai Perusahaan didefinisikan sebagai nilai pasar karena memberikan kemakmuran para pemegang saham. Harga saham yang semakin tinggi menyebabkan semakin tinggi pula nilai perusahaan. Nilai perusahaan yang tinggi menjadi keinginan para pemilik perusahaan, sebab dengan nilai yang tinggi menunjukkan kemakmuran pemegang saham juga tinggi. Oleh sebab itu ada kemungkinan manajemen melakukan praktik perataan laba menjaga konsistensi atau kestabilan laba pada setiap periode maka, nilai perusahaan tetap terjaga. Nilai perusahaan yang tinggi akan meningkatkan harga saham sehingga deviden pun ikut meningkat dan ini akan terjadi perataan laba

\section{H2 :Pengaruh Ukuran Perusahaan terhadap Peratan Laba (Income Smoothing)}


Ukuran Perusahaan adalah Perusahaan yang ditunjukkan oleh total aktiva, jumlah penjualan, rata- rata total penjualan dan rata - rata total aktiva. Ukuran perusahaan yang besar umumnya akan banyak mendapatkan perhatian yang lebih besar dari pihak eksternal yaitu investor, pemerintah ataupun analis. Ukuran perusahaan yang besar akan meningkatkan asset dan menimbulkan tingginya respon investor dan perusahaan akan mengharapkan profittabilitas yang tinggi sehingga akan terjadi perataan laba

Diastiti Okkasisma (2010) melakukan penelitian tentang ukuran perusahaan terhadap perataan laba dan dari hasil penelitiannya menyatakan bahwa ukuran perusahaan berpengaruh signifikan terhadap perataan laba hal ini sejalan dengan penelitian Ummi Murtni adiitya Deny O.S (2012) berdasarkan keterkaitan diatas, maka hipotesis yang diajukan

H2 : Ukuran perusahaan berpengaruh terhadap perataan laba(income smoothing)

H2a : Kepemilikan Manajerial memoderatsi hubungan antara ukuran perusahaan terhadap perataan laba (income smoothing)

$\mathrm{H} 2 \mathrm{~b}$ : Kepemilikan Institusional memoderasi hubungan antara ukuran perusahaan terhadap perataan laba (income smoothing)

\section{H3 :Pengaruh Earning Per Share terhadap Perataan Laba}

Earning Per Share adalah rasio yang menunjukkan berapa besar keuntungan yang diperoleh investor atau pemegang saham per lembar saham. Earning per share menggambarkan profitabilitas perusahaan yang tergambar pada setiap lembar saham yang di peroleh perusahaan dalam periode waktu tertentu
EPS yang tinggi menjadi tujuan utama perusahaan karena memaksimalkan kesejahteraan pemegang saham semakin tinggi nilai EPS maka kemampuan perusahaan untuk memberikan pendapatan kepada pemegang sahamnya semakin tinggi sehingga terjadi perataan laba

Berdasarkan penelitian yang dilakukan oleh Haryanto (2013) yang menyatakan bahwa Earning pershare berpengaruh terhadap praktek perataan laba. Berdasarkan keterkaitan diatas, maka hipotesis yang diajukan

H3 : Earning per Share berpengaruh terhadap perataan laba (income smoothing)

H3a : Kepemilikan Manajerial memoderatsi hubungan antara ukuran perusahaan terhadap perataan laba (income smoothing)

$\mathrm{H} 3 \mathrm{~b}$ : Kepemilikan Institusional memoderatsi hubungan antara ukuran perusahaan terhadap perataan laba (income smoothing)

\section{H4 :Pengaruh Kepemilikan Manajerial terhadap Perataan Laba}

Kepemilikan manajerial adalah jumlah kepemilikan saham oleh pihak manajemen dari seluruh modal saham perusahaan yang dikelola (Gideon,2005) dalam (Agustin,2016). Kepemilikan Manajerial Konflik keagenan disebabkan oleh adanya pemisahan kepemilikan dan pengendalian dalam perusahaan. Dinyatakan bahwa semakin terkonsentrasi kepemilikan perusahaan pada satu orang maka kendali akan menjadi semakin kuat dan cenderung menekan konflik keagenan. Jensen dan Meckling (1976) yang menyatakan bahwa semakin besar proporsi kepemilikan manajemen dalam suatu perusahaan maka manajemen akan berupaya lebih giat untuk memenuhi 
kepentingan pemegang saham yang juga adalah dirinya sendiri dan ini akan menyebabkan terjadinya perataan laba.

H4 : Kepemilikan Manajerial berpengaruh terhadap perataan laba (income smoothing)

\section{H5 :Pengaruh Kepemilikan Institusional terhadap Perataan Laba}

Kepemilikan institutional adalah saham perusahaan yang dimiliki oleh institusi atau lembaga (perusahaan asuransi, bank, perusahaan investasi dan kepemilikan institusi lain) (Midiastuty dan Machfoedz, 2003). Terdapat dua pendapat yang bertentangan menyangkut kepemilikan institusional pendapat pertama, yaitu berdasar pada pandangan bahwa kepemilikan institusional adalah pemilik sementara yang biasa terfokus pada current earning sehingga manajer terpaksa melakukan tindakan meningkatkan laba. Pendapat kedua yaitu kepemilikan institusional adalah shophisiticated sehingga dapat melakukan fungsi monitoring secara lebih efektif dan tidak mudah di perdaya atau percaya dengan tindakan manipulasi oleh manajer.

H5 : Kepemilikan Institusional berpengaruh terhadap perataan laba (income smoothing)

\section{kerangka Pemikiran}

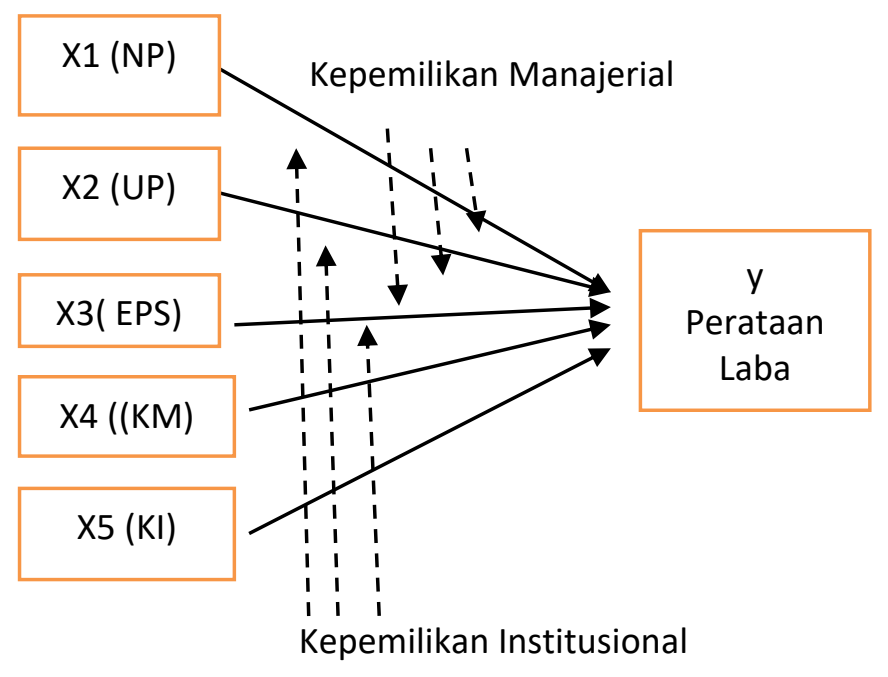

Gambar 2

Rerangka Pemikiran Teoritis

\section{METODE PENELITIAN}

Penelitian ini menggunakan data kuantitatif, dan merupakan data sekunder. Data sekunder yang digunakan berasal dari laporan keuangan tahunan yang terdaftar pada Bursa Efek Indonesia (BEI) adapun periode penelitian ini mencakup waktu lima tahun yakni tahun 2012 s.d. 2016. Data penelitian ini diperoleh secara tidak langsung melalui media perantara, yakni literature Pusat Regferensi Pasar Modal Bursa Efek Indonesia, Indonesian Capital Market Library )ICAMEL), Indonesian Capital Market Directory (ICMD) dan situs BEI (www.idx.co.id)

Populasi yang digunakan dalam penelitian ini adalah perusahaan go publikyang terdaftar di bursa efek indoenesia sementara sampelnya adalah 70 perusahaan perbankan swasta di Indonesia. Pengambilan sampel menggunakan teknik purposive sampling yaitu pemilihan sampel secara tidak acak yang informasinya diperoleh dengan kriteria atau pertimbangan tertentu(Indriantoro dan Supomo, 1999 
Tabel 1

Operasionalisasi Variable Penelitian

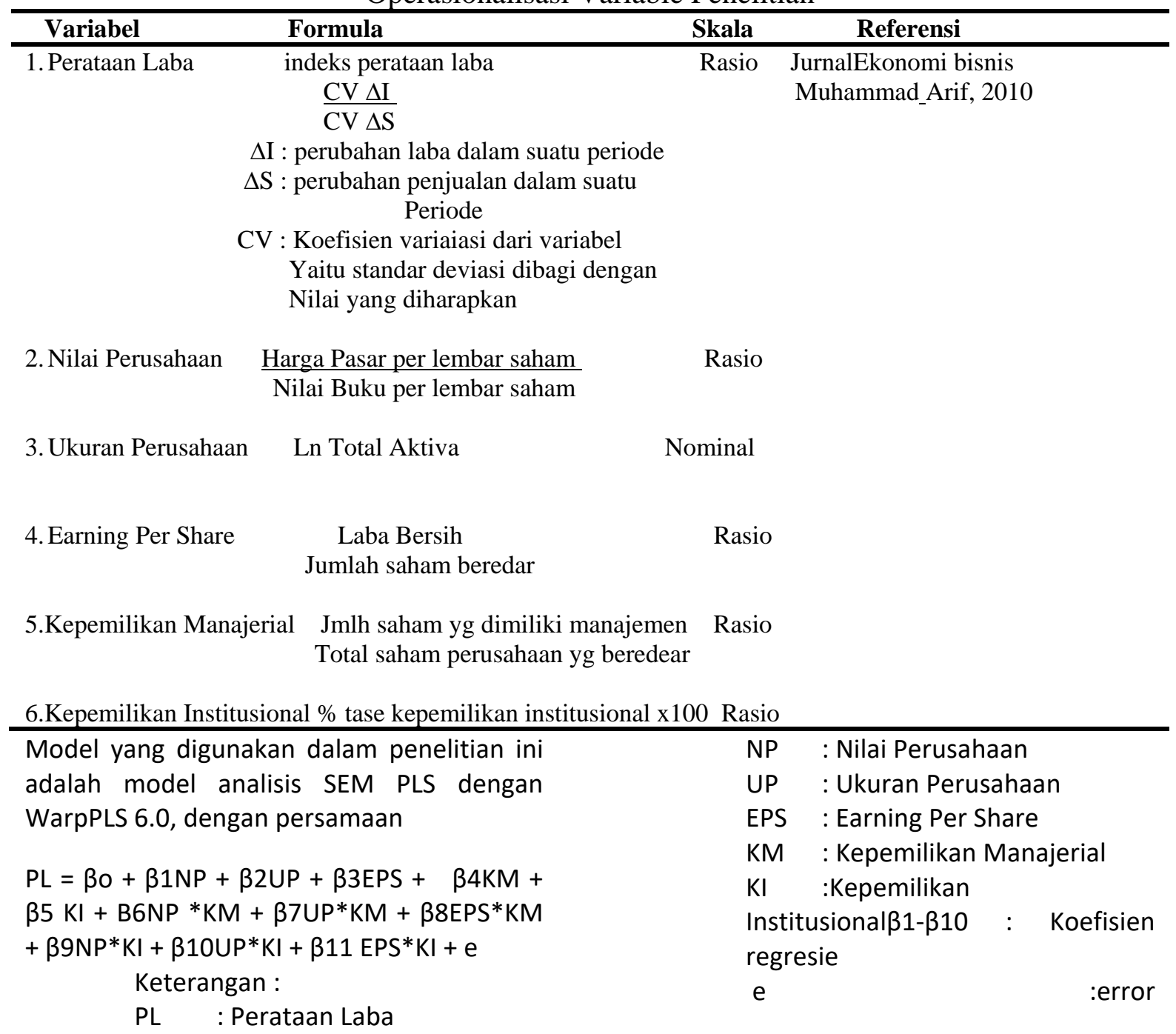




\section{HASIL PENELITIAN DAN PEMBAHASAN HASIL PENELITIAN}

Tabel 2

Deskriptif Statistik

\begin{tabular}{lcccccc}
\hline & PLABA(Y) & PBV(X1) & SIZE(X2) & EPS(X3) & KM(M1) & KI(M2) \\
\hline Min & -0.267 & -1.151 & -0.674 & -0.939 & -0.465 & -2.112 \\
Max & 3.474 & 1.979 & 2.912 & 2.693 & 2.489 & 1.374 \\
Median & -0.267 & -0.295 & -0.42 & -0.486 & -0.465 & -0.079 \\
Mode & -0.267 & -1.151 & -0.674 & -0.939 & -0.465 & -2.112 \\
Mean & 1.6035 & 0.414 & 1.119 & 0.877 & 1.012 & -0.369 \\
\hline
\end{tabular}

sumber : Indonesian Capital Market Directory, yang diolah kembali (2018)

\begin{abstract}
Statistik Deskriptif tentang variabel penelitian menggambarkan bahwa variabel Perataan Laba memiliki nilai minimum sebesar -0.267 artinya
\end{abstract} Perusahaan yang melakukan perataan pajak sebanyak 26,7 \% dari jumlah sampel penelitian adapun nilai maksimum sebesar 3.474 yang berarti sampel perusahaan penelitian maksimal sebanyak $34 \%$ melakukan perataan pajak. Nilai median sebesar -0.267 artinya perusahaan memiliki nilai tengah $26,7 \%$ dan mean 1.6035 artinya rata rata dimana perusahaan yang melakukan perataan laba sebesar 16,35 \%. Dimana perusahaan yang melakukan perataan laba mempunyai resiko dalam laporan keuangan yaitu adanya indikasi kesulitan keuangan

Variabel PBV memiliki nilai minimum sebesar -1.151 artinya Perusahaan yang memiliki harga saham di atas harga pasar sebanyak $11,5 \%$ dari jumlah sampel penelitian adapun nilai maksimum sebesar 1.979 yang berarti dari sampel perusahaan penelitian maksimal sebanyak $19,7 \%$ tidak memiliki harga saham di atas harga pasar Nilai median sebesar -0.295 artinya perusahaan dengan nilai tengah sebesar 29,5\% memiliki harga saham diatas harga pasar. Nilai mean sebesar 0.414. artinya perusahaan memiliki rata - rata harga saham di atas harga pasar sebanyak 41,4 $\%$
Variabel Size memiliki nilai minimum sebesar --0.674, artinya Perusahaan yang memiliki total asset yang besar sebanyak $67,4 \%$ dari jumlah sampel penelitian adapun nilai maksimum sebesar 2.912 yang berarti dari sampel perusahaan penelitian maksimal sebanyak $29 \%$ memiliki total asset yang besar. Nilai median sebesar -0.42 artinya perusahaan dengan nilai tengah $42 \%$ memiliki asset yang tidak besar. Nilai mean 1.119 artinya perusahaan rata-rata memiliki total asset yang besar sebesar 11,1\%

$$
\text { Variabel EPS memiliki nilai }
$$
minimum sebesar, -0.939 artinya Perusahaan yang memiliki laba bersih yang besar sebanyak $93 \%$ dari jumlah sampel penelitian adapun nilai maksimum sebesar 2.693 yang berarti dari sampel perusahaan penelitian maksimal sebanyak 26,9 \% memiliki laba bersih yang tinggi. Nilai median sebesar - 0.486 artinya perusahaan dengan nilai tengah sebesar 48,6 \% memiliki laba bersih yang tinggi. Nilai mean 0.877 artinya perusahaan memiliki rata - rata laba bersih yang tinggi sebesar $87,7 \%$.

Variabel KM memiliki nilai minimum sebesar -0.465 , artinya Perusahaan yang memiliki saham oleh pihak manajemen sebesar $46,5 \%$ dari jumlah sampel penelitian adapun nilai maksimum sebesar 2.489 yang berarti dari sampel perusahaan penelitian maksimal sebanyak 24,8 \% memiliki saham yang 
dimiliki oleh pihak manajemen. Nilai median sebesar -0.465 artinya perusahaan dengan nilai tengah sebesar $46,5 \%$ Nilai mean 1.012 artinya perusahaan dengan rata-rata mempunyai saham yang dimiliki oleh pihak manajemen sebesar 10,1\%.

$$
\text { Variabel KI memiliki nilai }
$$

minimum sebesar -2.112, artinya Perusahaan yang memiliki saham oleh pihak institusi sebesar 21,1\% dari jumlah sampel penelitian adapun nilai maksimum sebesar 1.374 yang berarti dari sampel perusahaan penelitian maksimal sebanyak 13,7 \% memiliki saham yang dimiliki oleh pihak institusi. Nilai median sebesar -0.079 artinya perusahaan dengan nilai tengah $7,9 \%$. Nilai mean -0.369 artinya perusahaan rata-rata mempunyai saham yang dimiliki oleh pihak institusi sebesar $36,9 \%$.

\section{Uji Hipotesis}

Pengujian hipotesis ini dimaksudkan untuk menjawab pertanyaan-pertanyaan penelitian yang dilakukan. Dalam pengujian hipotesis dengan menggunakan alat analisis Structural Equaton Modeling (SEM) dengan program WarpPLS 6.00 berikut ini disajikan pengujian hipotesis dari model penelitian ini.

\section{Pengujin Full Model dengn Double Moderator}

Untuk dapat menjawab hipotesis penelitian maka harus dilakukan pembuatan SEM Model yang menggambarkan hubungan kauslitas dengn double moderator antar vriabel; maka setelah run-test diperoleh model sebagai berikut

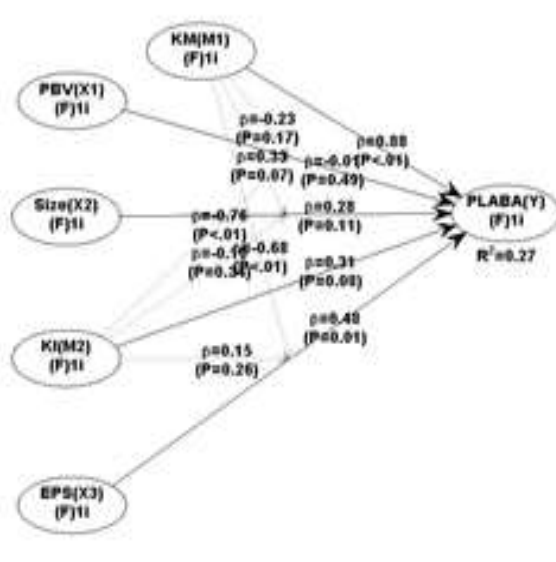

Gambar 3

Full Model Dengan Double Moderator

Gambar diatas menunjukkan hubungan kausalitas antar variabel, dimana Nilai, ukuran perusahaan, earning per share, kepemilikan manajerial sebagai variabel independen dan perataan laba sebagai variabel dependen. Dimana di moderasi oleh kepemilikan manajerial dan kepemilikan institusional.

Hasil pengujian pengaruh PBV terhadap perataan laba adalah tidak signifikan dengan koefisen jalur - 0,01 p-value sebesar 0,49 . Size terhadap perataan laba adalah tidak signifikan dengan koefisien jalur 0,28 p-value 0,11 EPS terhadap perataan laba adalah positif signifikan dengan koefisien jalur 0,48 p-jalur 0,01 kepemilikan manajerial adalah positif signifikan dengan koefisien 0,88 p-value $<.01$ kepemilikan institusional adalah positif signifikan dengan koefisien 0,31 p-value 0,08 dan KM memoderasi PBV terhadap perataan laba tidak signifikan dengan koefisien 0,23 p-value $0,17 \mathrm{KI}$ memoderasi PBV terhadap perataan laba $\mathrm{p}<.01$ 
Tabel 3 Model Fit and Quality Indices

Model fit and quality indices

\begin{tabular}{|c|c|c|}
\hline \multicolumn{3}{|c|}{ Average path coeffimacient $(\mathrm{APC})=0.383, \mathrm{P}=0.020$} \\
\hline \multicolumn{3}{|c|}{ Average R-squared (ARS) $=0.269, \mathrm{P}=0.060$} \\
\hline \multicolumn{3}{|c|}{ Average adjusted $\mathrm{R}$-squared (AARS) $=-3.749, \mathrm{P}=0.000$} \\
\hline \multicolumn{3}{|c|}{ Average block VIF $(\mathrm{AVIF})=332.701$, acceptable if $<=5$, ideally $<=3.3$} \\
\hline \multicolumn{3}{|c|}{ Average full collinearity VIF (AFVIF) $=3,3 \operatorname{Inf}$, acceptable if $<=5$, ideally $<=3.3$} \\
\hline Jalur & Coeffecients & P-Value \\
\hline $\mathrm{PBV} \rightarrow \mathrm{P}(\mathrm{LABA})$ & 0,01 & 0,49 \\
\hline $\mathrm{SIZE} \rightarrow \mathrm{P}(\mathrm{LABA})$ & 0,28 & 0,11 \\
\hline $\mathrm{EPS} \rightarrow \mathrm{P}(\mathrm{LABA})$ & 0,48 & 0,01 \\
\hline $\mathrm{KM} \rightarrow \mathrm{P}(\mathrm{LABA})$ & 0,88 & $<0,01$ \\
\hline $\mathrm{KI} \rightarrow \mathrm{P}(\mathrm{LABA})$ & 0,31 & 0,08 \\
\hline \multicolumn{3}{|l|}{ Moderation } \\
\hline $\mathrm{PBV} * \mathrm{KM} \rightarrow \mathrm{P}(\mathrm{LABA})$ & 0,23 & 0,17 \\
\hline $\mathrm{PBV} * \mathrm{KI} \rightarrow \mathrm{P}(\mathrm{LABA})$ & 0,76 & $<.01$ \\
\hline SIZE $* \mathrm{KM} \rightarrow \mathrm{P}(\mathrm{LABA})$ & 0,76 & 0,07 \\
\hline $\mathrm{SIZE}^{*} \mathrm{KI} \rightarrow \mathrm{P}(\mathrm{LABA})$ & 0,10 & $<.01$ \\
\hline $\mathrm{EPS} * \mathrm{KM} \rightarrow \mathrm{P}(\mathrm{LABA})$ & 0,48 & 0,01 \\
\hline EPS* $\mathrm{KI} \rightarrow \mathrm{P}(\mathrm{LABA})$ & 0,15 & 0,26 \\
\hline
\end{tabular}

Sumber : data diolah (2018)

Berdasarkan output model fit and quality indices mempunyai nilai Average Berdasarkan output model fit and quality indices mempunyai nilai Average Average adjusted R-squared (AARS) $=-$ 0.269, $\mathrm{P}=0.060$, AVIF $=332.701$, acceptable if $<=$ 5 , ideally $<=3.3$, AFVIF $=$, acceptable if $<=5$, ideally $<=3.3$ dan GoF $(\mathrm{GoF})=0.519$, small $>=0.1$, medium $>=0.25$, large $>=$ 0.36 .

Ketentuan untuk WarpPLS menyatakan bahwa nilai $\mathrm{p}$ untuk $\mathrm{APC}$ dan ARS harus lebih kecil dari 0,05 (signifikan). Nilai AVIF dan AFVIF sebagai indicator multikolonearitas harus lebih kecil dari 5 serta ketentuan untuk nilai GiF yaitu small $>=0.1$, medium $>=0.25$, large $>=0.36$. mengacu pada ketentuan tersebut, dapat disimpulkan bahwa model penelitian ini ada fit.

\section{Pengujian R - Squared, Q- Squared and Collinearity VIF}

Hasil pengolahan data atas $R$-Squared, $Q$ Squared and Full Collinearity VIF dapat disajikan sebagai berikut ini :

Tabel 4 Pengujian R - Squared, Q-Squared and Collinearity VIF

\begin{tabular}{lc}
\hline$R$-Squared, & \\
\hline $\mathrm{P}(\mathrm{LABA})$ & 0,269 \\
$\mathrm{Q}$-Squared & \\
$\mathrm{P}(\mathrm{LABA})$ & 0,923 \\
\hline
\end{tabular}

Sumber : Data olahan digunakan dalam penelitian ini (2018)

Hasil output R-Squared dilihat besarnya R-Squared 0,3 yang memiliki arti bahwa pengaruh variabel nilai perusahaan, ukuran perusahaan, eps, kepemilikan manajerial dan kepemilikan institusi sebesar 30\% (0,269 dibulatkan) dan sisanya sebesar $70 \%$ dipengaruhi oleh variabel diluar penelitian ini. Adapun hasil pengujian hipotesis dapat dirangkum pada tabel model penelitian empiris sebagai berikut 
Tabel 5 Rangkuman Hasil Pengujian Hipotesis

\begin{tabular}{|c|c|c|c|c|}
\hline No & $\begin{array}{l}\text { Hubungan Antar } \\
\text { Variabel }\end{array}$ & Hipotesis & P-Value & HASIL \\
\hline 1 & PBV Terhadap P (laba) & H1 & 0,49 & Ditolak \\
\hline 2 & SIZE Terhadap P (laba) & $\mathrm{H} 2$ & 0.10 & Ditolak \\
\hline 3 & EPS Terhadap P (laba) & $\mathrm{H} 3$ & $0.01^{*}$ & Diterima \\
\hline 4 & KM Terhadap P (LABA) & $\mathrm{H} 4$ & $0.001 * *$ & Diterima \\
\hline 5 & KI Terhadap P(laba) & H5 & $0.08 * *$ & Diterima \\
\hline 6 & PBV Terhadap P(laba) Moderasi KM & H1a & 0.168 & Ditolak \\
\hline 7 & PBV Terhadap P(laba) Moderasi KI & $\mathrm{H} 1 \mathrm{~b}$ & $<0,01^{*}$ & Full Moderasi \\
\hline 8 & SIZE Terhadap P(laba) Moderasi KM & $\mathrm{H} 2 \mathrm{a}$ & $0.07 * *$ & Full Moderasi \\
\hline 9 & SIZE Terhadap P(LABA) Moderasi KI & $\mathrm{H} 2 \mathrm{~b}$ & 0,34 & Ditolak \\
\hline 10 & EPS Terhadap P(LABA) Moderasi KM & $\mathrm{H} 3 \mathrm{a}$ & $<0,01 * *$ & $\begin{array}{l}\text { Quasi } \\
\text { Moderasi }\end{array}$ \\
\hline 11 & EPS Terhadap P(LABA) Moderasi KI & $\mathrm{H} 3 \mathrm{~b}$ & 0.001 & Ditolak \\
\hline
\end{tabular}

Sumber : data diolah digunakan dalam penelitian ini (2018)

*Signifikan pada level $5 \%$

** Signifikan pada level $10 \%$

\section{PEMBAHASAN}

\subsection{Pengaruh Price Book Value Terhadap Perataan Laba}

Pengujian hipotesis $\mathrm{H}_{1}$ menunjukkan bahwa pada persamaan model variabel Nilai Perusahaan (PBV) tidak berpengaruh secara signifikan terhadap perataan laba, dengan coefisien sebesar 0,01 dan $p$-value sebesar 0,49 (lebih besar dari 0,05). Hasil ini menunjukkan bahwa selama periode penelitian PBV tidak berpengaruh terhadap perataan laba. Nilai perusahaan tidak signifikan terhadap perataan laba hal ini disebabkan oleh laba yang dihasilkan oleh perusahaan tersebut tidak stabil

Hasil penelitian ini sejalan dengan peelitian yang dilakukan oleh Noviana dan Yuyetta (2010), yang menyatakan nilai perusahaan tidak berpengaruh terhadap perataan laba. Dan bertentangan dengan penelitian yang dilakukan oleh Cahyani (2010) yang membuktikan bahwa nilai perusahaan berpengaruh terhadap perataan 
laba.dengan perbedaan data yang diambil melalui jakart Islamic indeks, dan sampel berbagai perusahaan

\subsection{Pengaruh Ukuran Perusahaan (Size) terhadap Perataan Laba} Pengujian hipotesis $\mathrm{H}_{2}$ menunjukkan bahwa pada persamaan model variabel size dengan koefisien sebesar 0,28 dan p-value sebesar 0,11 (lebih besar dari 0,05).berpengaruh signifikan terhadap perataan laba. Hasil ini menunjukkan bahwa selama periode penelitian Hal ini diduga karena aset perusahaan yang tidak dimanfaatkan untuk memperoleh profitabilitas. Sehingga aset yang dimiliki belum mampu mendorong terciptanya keuntungan perusahaan,. Hal ini sejalan dengan peneltian yang dilakukan oleh Sherlita dan Kurniawan (2013), Cahyani (2012) yang menyatakan bahwa ukuran perusahaan tidak berpengaruh terhadap perataan laba. dengan perbedaan data yang diambil melalui jakart Islamic indeks, dan sampel berbagai perusahaan

\subsection{Pengaruh EPS Terhadap Perataan Laba}

Pengujian hipotesis $\mathrm{H}_{3}$ menunjukkan bahwa pada persamaan model variabel EPS berpengaruh positif signifikan terhadap perataan laba, dengan koefisien sebesar 0,28 dan p-value sebesar 0,01 (lebih kecil dari 0,05)

laba bersih yang didapat penelitian ini mengindikasikan adanya perataan laba hal ini sejalan dengan penelitian yang dilakukan oleh Indrimeidini (2017) yang menyatakan bahwa EPS berpengaruh positif dan signifikan terhadap perataan laba. hal ini sesuai dengan teori agensi yaitu pemegang saham mendelegasikan pengambilan keputusan bisinis kepada manjer (perusahaan ). Dan bertentangan terhadap penelitian yang dilakukan oleh Fahrurozi (2017) yang menyatakan bahwa EPS tidak berpengaruh negatif dan tidak signifikan terhadap perataan laba, dengan perbedaan pada jenis sample yang diteliti adalah perusahaan manufaktur

\subsection{Peng.aruh Kepemilikan Manajerial Terhadap Perataan Laba}

Pengujian hipotesis $\mathrm{H}_{5}$ menunjukkan bahwa pada persamaan model variabel Kepemilikan Manajerial berpengaruh secara signifikan terhadap perataan laba, dengan koefisien sebesar 0,31 dan $\mathrm{p}$ value sebesar 0,08 (lebih kecil dari 0,10). Hasil penelitian ini menunjukkan bahwa kepemilikan manajerial mampu membuat mekanisme kontrol internal dalam perusahaan untuk melakukan perataan laba. Hasil penelitian ini sejalan dengan penelitian yang dilakukan oleh Herlinda Pratiwi dan Bestari Dwi Handayani(2014), hal ini sesuai dengan teori agensi yaitu pemegang saham mendelegasikan pengambilan keputusan bisinis kepada manjer (perusahaan ) tetapi hal ini bertentangan dengan penelitian yang dilakukan oleh $\mathrm{Ni}$ Kadek Budi Puspitasari (2016). Dengan perbedaan penelitian adalah jenis sampel perusahaan adalah perusahaan manufaktur

\subsection{Pengaruh Kepemilikan}

Institusional Terhadap Perataan Laba

Pengujian hipotesis $\mathrm{H}_{6}$ menunjukkan bahwa pada persamaan model variabel Kepemilikan Institusional berpengaruh secara signifikan terhadap perataan laba, dengan koefisien sebesar 0,31 dan $\mathrm{p}$ value sebesar 0,08 (lebih kecil dari 0,10). Hasil penelitian ini menunjukkan bahwa kepemilikan Institusional sangat berperan dalam mekanisme kontrol eksternal terhadap perusahaan untuk melakukan perataan laba. Hasil penelitian ini sejalan dengan penelitian yang dilakukan oleh (Purwaningtyas,2011), hal ini sesuai dengan teori agensi yaitu pemegang saham mendelegasikan pengambilan keputusan bisinis kepada manjer 
(perusahaan) tetapi hal ini bertentangan dengan penelitian yang dilakukan oleh Shleifer dan Vishnya (1997) dengan perbedaan penelitian yaitu pada perusahaan manufaktur

5.6. Pengaruh Nilai Perusahaan (PBV) Terhadap Perataan Laba dengan Kepemilikan Manajerial sebagai Pemoderasi

Pengujian hipotesis H1a .amenunjukkan bahwa pada persamaan model variabel Kepemilikan Manajerial tidak memoderasi hubungan antara Nilai Perusahaan (PBV) terhadap Perataan Laba dengan koefisien sebesar 0,23 dan p-value sebesar 0,17 (lebih besar dari 0,05). Dengan demikian Kepemilikan Manajerial tidak memoderasi hubungan antara PBV terhadap P(Laba).

\subsection{Pengaruh Nilai Perusahaan (PBV)} Terhadap Perataan Laba dengan

Kepemilikan Institusional sebagai Pemoderasi

Pengujian hipotesis $\mathrm{H} 1 \mathrm{~b}$ amenunjukkan bahwa pada persamaan model variabel Kepemilikan Institusional memoderasi hubungan antara Nilai Perusahaan (PBV) terhadap Perataan Laba dengan Koefisien sebesar - 0,68 dan p-value sebesar 0,01 (lebih kecil dari 0,05). Dengan demikian Kepemilikan Manajerial sebagai full moderasi hubungan antara pbv terhadap Perataan Laba

5.8. Pengaruh Ukuran Perusahaan (Size) Terhadap Perataan Laba dengan Kepemilikan Manajerial sebagai Pemoderasi

Dari hasil olah data untuk pengujian hipotesis $\mathrm{H} 2 \mathrm{a}$ amenunjukkan bahwa pada persamaan model variabel Kepemilikan Manajerial memoderasi hubungan antara Size terhadap Perataan Laba dengan koefisien sebesar 0,33 dan p-value sebesar 0,07 (lebih kecil dari 0,10). Dengan demikian Kepemilikan Manajerial sebagai full moderasi hubungan antara Size terhadap Perataan Laba. Artinya tidak ada pemoderasi lain selain kepemilikan manajerial

5.9. Pengaruh Ukuran Perusahaan (Size) Terhadap Perataan Laba dengan Kepemilikan Institusional sebagai Pemoderasi

Dari hasil olah data untuk pengujian hipotesis $\mathrm{H} 2 \mathrm{~b}$ amenunjukkan bahwa pada persamaan model variabel Kepemilikan Institusional memoderasi hubungan antara Size terhadap Perataan Laba dengan Koefisien sebesar 0,10 dan $\mathrm{p}$ value sebesar 0,34 (lebih besar dari 0,05). Dengan demikian Kepemilikan Institusi tidak memoderasi hubungan antara Size terhadap Perataan Laba.

\subsection{Pengaruh EPS Terhadap Perataan} Laba dengan Kepemilikan Manajerial sebagai Pemoderasi

Dari hasil olah data untuk pengujian hipotesis H3a menunjukkan bahwa pada persamaan model variabel Kepemilikan Manajerial memoderasi hubungan antara EPS terhadap Perataan Laba dengan koefisien sebesar 0,33 dan $p$-value sebesar 0,07 (lebih kecil dari 0,10). Dengan demikian Kepemilikan Manajerial sebagai partial moderasi hubungan antara EPS terhadap Perataan Laba. Artinya ada pemoderasi lain selain kepemilikan manajerial.

.5.1. Pengaruh EPS Terhadap Perataan Laba dengan Kepemilikan Institusional sebagai Pemoderasi

Dari hasil olah data untuk pengujian hipotesis H3b menunjukkan bahwa pada persamaan model variabel Kepemilikan Institusional memoderasi hubungan antara EPS terhadap Perataan Laba dengan koefisien sebesar 0,15 dan $\mathrm{p}$ value sebesar 0,26 (lebih besar dari 0,05). Dengan demikian Kepemilikan Institusi tidak memoderasi hubungan antara EPS terhadap Perataan Laba 


\section{Simpulan, Keterbatasan Dan Implikasi Hasil Penelitian}

Berdasarkan pengujian dan pembahasan yang disajikan di bab-bab sebelumnya, dapat disimpulkan beberapa temuan yang terkait dengan hipotesis penelitian, antara lain

Nilai Perusahaan tidak berpengaruh positif terhadap perataan laba, Size tidak berpengaruh terhadap peratan laba. EPS berpengaruh terhadap perataan laba.

Kepemilikan Manajerial berpengaruh positif terhadap perataan laba. Kepemilikan Institusional berpengaruh terhadap perataan laba. Kepemilikan Manajerial tidak memoderasi hubungan antara Nilai Perusahaan (PBV) terhadap Perataan Laba

Kepemilikan Institusional dengan full moderasi hubungan antara Nilai Perusahaan (PBV) terhadap Perataan Laba Kepemilikan Institusional tidak memoderasi hubungan antara Ukuran Perusahaan (Size) terhadap Perataan Kepemilikan Manajerial pure moderasi hubungan antara EPS terhadap Perataan Laba Kepemilikan Institusi tidak memoderasi hubungan antara EPS terhadap Perataan Laba Penelitian ini dilakukan pada perusahaan jasa keuangan yang terdaftar di Bursa Efek Indonesia, dengan keterbatasan antar lain : Pengambilan sampel sedikit sehingga perusahaan ini tidak dapat di moderasi, hal ini dapat diatasi dengan menambah sampel penelitain selain perusahaan perbankan. Mengganti price Book value dengan variabel lain misalnya Per lebih mudah dicari karena hanya focus pada laba bersih

\section{DAFTAR PUSTAKA}

Dewi, Diastiti Okkarisma. 2010. Pengaruh Jenis Usaha, Ukuran Perusahaan dan Financial Leverage Terhadap Tindakan Perataan Laba Pada Perusahaan Yang Terdaftar Di Bursa Efek Indonesia. Skripsi Fakultas Ekonomi Universitas Diponegoro Semarang.

Fachrorozi,dan Ni Kadek Sinarwati, 2017 Pengaruh cash holding, harga saham perusahaan, dan Earning Pershare terhadap Income Smooting (Studi Empiris Perusahaan Manufaktur) yang terdaftar di Bursa Efek Indonesia. Jurnal Akuntansi Vol.7 No.1 Tahun 2017

Jogiyanto,H.M.(2010), Teori Portofolio dan analisis investasi, edisi ketujuh, cetakan pertama, BPFE Yogyakarta

Jogiyanto,H.M.(2005), Metodologi Penelitian Bisnis, Salah Kaprah dan Pengalaman - Pengalaman, edisi 2004/2005, Yogyakarta

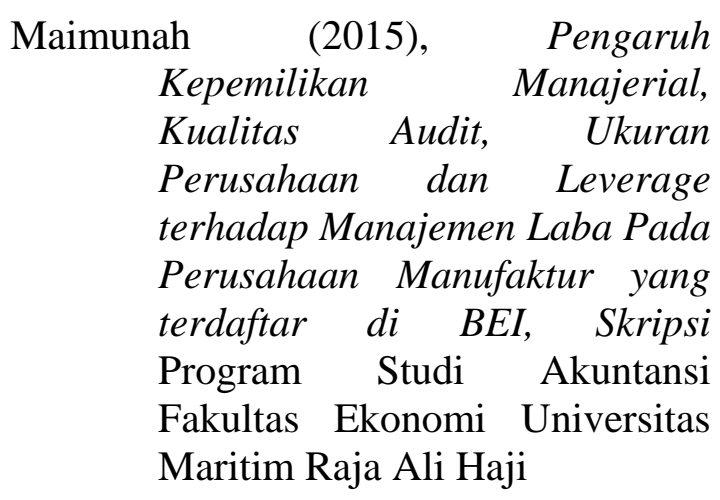

Muhammad Fahmi Arif (2010), Analisis Pengaruh Nilai Perusahaan, Kebijakan Deviden, Reputasi Auditor dan Ukuran Perusahaan 
terhadap Praktik Perataan Laba, (Studi pada Perusahaan Manufaktur Yang Terdaftar Di BEI Periode 2009-2010 ) Jurnal Akuntansi

Ni Kadek Budi Puspitasari (2016)

Pengaruh Profitabilitas pada Praktik Perataan Laba dengan Struktur Kepemilikan sebagai Variabel Pemoderasi,Jurnal Akuntansi Vol. 2.3.1 April (2018)

Ni Wayan Piwi Indah Pratiwi dan I Gst. Ayu Eka Daayanti (2015), Analisis Perataan Laba dan Faktor- Factor Yang Mempengaruhinya, Jurnal Akuntansi Vol. 20.1,Juli 2017

Noviana dan Yuyetta (2011) Analisis factor - factor yang mempengaruhi praktik perataan laba (studi empiris pada perusahaan manufaktur (BEI th 2006 - 2010),Jurnal Akuntansi dan Auditing Vol.8 No.1 tahun 2011

Sugiyono (2013), Metode Penelitian Bisnis, cetakan ketujuh belas, Alfabeta, Bandung

Suharto dan I Ketut Sujana (2016), Pengaruh Nilai Saham, Profitabilitas dan Pajak Penghasilan Terhadap Perataan Laba, Jurnal Akuntansi, Vol. 17.3, Desember, 2016

Syahril Djaddang, Amelia Oktarivina dan E. Sulistiawarni (2018), Model Manajemen Akrual (Artificial Smoothing) dan Volatilitas Laba
Pada Perusahaan Hedged di Indonesia, CV. Tiga Media, Utama Semarang

Sofyan Yamin dan Heri Kurniawan (2009), Struktural Equation Modeling, Salemba

Suci Anggani1, Muhammad Rafki Nazar( 2013), Pengaruh Kepemilikan Manajerial, Kepemilikan Institusional dan Leverage Terhadap Praktik Manajemen Laba, Jurnal Manajemen: Vol.2, No.3 Desember 2015

Umi Murtini dan Aditya Denny O.S (2012), Ukuran Perusahaan, Profitabilitas, Financial Leverage, Dividend Payout Ratio dan Kecenderungan Perataan Laba, Jurnal Akuntansi Vol. 8 No.2 Agustus 2012

Yashinta Pradimitha Cindy (2013), Pengaruh cash holding, profitabilitas, dan nilai perusahaan terhadap income smooting, Skripsi Program Sarjana Fakultas Ekonomika dan Bisnis Universitas Diponegoro

Zulia Oviani (2013) Pengaruh Ukuran Perusahaan, Profitabilitas, Financial Leverage dan Kepemilikan Institusional Terhadap Perataan Laba Pada Perusahaan Manufaktur yang terdaftar di BEI (20092013),JUrnal FEKON Vol. 1 No. 2 Oktober 2014 
JURNAL AKUNIDA ISSN 2442-3037 VOLUME 5 NOMOR 1, JUNI 2019 | 53 